\title{
WHAT NOT TO WEAR: RELIGIOUS RIGHTS, THE EUROPEAN COURT AND THE MARGIN OF APPRECIATION
}

\section{INTRODUCTION}

The issue of religious dress, specifically female Muslim religious dress, has been the subject of intense controversy within Europe over recent years. In the United Kingdom comments by Jack Straw MP, Leader of the House of Commons and a former Home and Foreign Secretary, that he felt uncomfortable talking to women at his constituency surgery who wore the Muslim veil sparked a storm of intense and, at times, acrimonious debate. ${ }^{1}$ In France the banning of headscarves in state schools has provoked major controversy. ${ }^{2}$ In the Netherlands the Dutch parliament voted to ban the burka in public places ${ }^{3}$ and in five Belgian towns its wearing has been banned on pain of a fine. ${ }^{4}$ In several instances the battles between those wishing to wear clothing signifying religious belief, and those wishing to restrict them, have been fought out in the courts. ${ }^{5}$

Against a background of immigration, and concomitant racial, cultural and religious diversity $^{6}$ the issue has, at times, been portrayed as symbolic of a "clash of civilisations" ${ }^{\prime 7}$ between a liberal, pluralist, secular west valuing democracy, women's rights and personal autonomy and an irrational, repressive Islam whose adherents nevertheless, within that liberal secular state, have the right to religious freedom. The terrorist attacks in New York, Madrid and London have added to the sensitivity of the issue and brought it centre stage as part of the debate about the alleged disturbing "radicalisation" of Muslim youth. ${ }^{8}$ It has also become part of the current public conversation about the wisdom and success of the liberal state's commitment to pluralist multiculturalism. ${ }^{9}$

The legal and policy debate on the substantive rights and wrongs of restricting religious clothing is complex and has been covered extensively by academic and other

\footnotetext{
1 The Lancashire Telegraph 5 October 2006; The Guardian 6 October 2006; The Times 7 October 2006.

${ }^{2}$ Article L41-5-1 Education Code of 15 March 2004.

${ }^{3}$ Not implemented - pending an inquiry as to whether the ban is compatible with the Constitution, BBC Mark Mardell, 16 January 2006 (available at http://news.bbc.co.uk/2/hi/europe/4616664.stm).

${ }^{4}$ Ibid.

5 See eg in Germany, Bundesverfassungsgericht (BverfGE), 2 BverfGE 1436/02 Judgment of 24 September 2003 ("teacher-head scarf" decision); in the United Kingdom, $R$ (on the application of Begum) v Headteacher and Governors of Denbigh High School [2006] UKHL 15; in Switzerland, Dahlab v Switzerland App No 42393/98, admissibility decision (2001). The issue has not been confined to Europe see eg Li-ann Thio and Jackly Ling-Chien Neo "Religious Dress in Schools: The Serban Controversy in Malaysia" (2006) 55 ICLQ 671; C Mahabir "Adjudicating Pluralism: The Hijab, Law and Social Change in Post-Colonial Trinidad" (2004) 13(4) Social and Legal Studies 435.

${ }^{6}$ See eg T Modood and P Werbner eds The Politics of Multiculturalism in the New Europe (Zed Books London 1997); B Parekh Rethinking Multiculturalism: Cultural Diversity and Political Theory (Macmillan London 2000); S Knights "Religious symbols in the school: freedom of religion, minorities and education” (2005) 5 European Human Rights Law Review 499.

${ }^{7}$ S Huntingdon "The Clash of Civilizations" (1993) 72 Foreign Affairs 22.

${ }^{8}$ See eg John Reid MP, Home Secretary, Speech 20 September 2006; Eliza Manningham-Buller, Director General of the Intelligence Service, Speech 10 November 2006.

${ }^{9}$ See eg Ruth Kelly MP, Communities Secretary, Speech 24 August 2006; Trevor Phillips, Chairman of Commission for Racial Equality “After 7/7: Sleepwalking to Segregation”, Speech 22 September 2005.
} 
commentators. ${ }^{10}$ The purpose of this article is not to add directly to the substance of that debate. Rather it is to examine the approach of the European Court of Human Rights (the Court) to religious freedom generally, as viewed through the prism of its attitude towards religious dress.

The protection of the right to manifest religious belief through clothing, protected by Article 9 of the European Convention on Human Rights (ECHR), has been noticeably weak. This article will suggest that this is in fact symptomatic of a deeper problem: the inability of the Court to put its finger on quite why religious freedom is valued in the first place. The philosophical underpinnings are uncertain and unsatisfactory in comparison, for example, to freedom of political expression or private consensual sexual conduct. This uncertainty has led to an extremely deferential approach by the Court; a self-denying ordinance leading to a virtual absence of scrutiny of the actual circumstances of alleged violations of religious rights. It will be suggested that this may be inevitable, given the liberal, secular paradigm, not to mention the current international political climate, within which the Court operates. However, to religious adherents, this judicial deference in religious matters will look as if the leading human rights court in Europe is guilty of disparity of treatment; that it gives far greater protection to those rights (such as political expression and sexual autonomy) that it does have a clear conceptual grasp of, than those rights (such as freedom of religious belief) that it does not. Furthermore, given the status of the European Court, it is likely that the approach will ease the way for states wishing to curtail religious manifestation through dress.

This article adopts the following structure: part II considers the doctrine of the margin of appreciation and the way it has been applied in such a way as to give states more leeway when imposing restrictions on religious manifestation and expression than on other rights; part III lightly sketches the philosophical justifications for religious freedom and some of the problems to which these justifications give rise, suggesting that a lack of clarity in the conception of the philosophical underpinnings has led the Court to afford lesser levels of protection to religious rights; part IV outlines the Court's approach to the issue of religious dress, the issue which brings into sharp focus the problems sketched out in the previous sections; in particular the judgment of the Grand Chamber of the Court in Leyla Şahin v Turkey is considered; ${ }^{11}$ in part $\mathrm{V}$ it is contended that this approach amounts to a failure by the Court to play by its own "rules" in that it fails to undertake meaningful proportionality analyses in such cases; part VI concludes with a brief consideration of the possible knock on consequences throughout Europe of the deferential position adopted at Strasbourg.

\section{THE MARGIN OF APPRECIATION AND RELIGION: GOD PLAYING SECOND FIDDLE TO POLITICS AND SEX?}

\footnotetext{
${ }^{10}$ See eg F Raday "Culture Religion and Gender" (2003) 4 International Journal of Constitutional Law 663; D Lyon and D Spini, "Unveiling the Headscarf Debate" (2004) 12 (3) Feminist Legal Studies 333; G Davies, "Banning the Jilbab: Reflections on Restricting Religious Clothing in the Light of the Court of Appeal in SB v Denbigh High School" (2005) European Constitutional Law Review 511; J Habermas "Intolerance and Discrimination" (2003) 1 International Journal of Constitutional Law 2; Baroness Hale of Richmond in Begum (n 5) amongst many others. Of particular difficulty is the paradox that religious injunctions on women to wear particular clothing in public space have been portrayed by liberals as repressive; but cases are brought by women themselves claiming the right to wear this dress.

${ }^{11}$ (2007) 44 EHRR 5.
} 
Cases in which victims have claimed breaches of religious rights have been brought under Article $10 \mathrm{ECHR}$, the right to freedom of expression, and under Article 9 ECHR, the right to freedom of thought, conscience and religion. ${ }^{12}$ These Articles, in common with Articles 8 (private and family life) and 11 (association and assembly), possess a two paragraph structure which expressly allows for a balance to be struck between the individual's right and the greater social good. Interferences with fundamental rights must be in pursuit of one of the legitimate aims listed in the second paragraphs, they must be "prescribed by" or be "in accordance with" the law and they must be "necessary in a democratic society". This latter requirement has been held by the Court to mean that any interference must, on the particular facts of the case before it, be proportionate to the aim pursued, it must be designed to meet a "pressing social need" and the reasons given for the interference by the state must be "relevant and sufficient". It is at this point, the point at which the Court assesses the proportionality of state interference with a right, that the "margin of appreciation" has assumed importance as a major adjudicative tool in certain types of case.

The margin of appreciation is an international law doctrine of judicial self-restraint or deference. It figures prominently in the Court's case law concerning religion. ${ }^{13}$ The doctrine is entirely judge-made; it has no textual basis within the Convention itself. The Court's jurisdiction is of a supervisory nature and is subsidiary to the primary protection for rights provided by national authorities which are closer to the "vital forces of their countries". ${ }^{14}$ The doctrine's purpose, therefore, is to allow a degree of latitude to states as to how they protect the individual rights set out in the Convention. The margin has been held to be especially important in areas where there is said to be an absence of consensus or common practice across Europe, for example in the fields of morals and religion. ${ }^{15}$

Where questions concerning the relationship between State and religions are at stake, on which opinion in a democratic society may reasonably differ widely, the role of the national decision making body must be given special importance . . . It is not possible to discern throughout Europe a uniform conception of the importance of the significance of religion in society ... and the meaning or impact of the public expression of a religious belief will differ according to time and context . . Rules in this sphere will consequently vary from one country to another according to national traditions and the requirements imposed by the needs to protect the rights and freedoms of others and to maintain public order . . . Accordingly the choice of the extent and form such regulations should take must inevitably be left up to a point to the State concerned, as it will depend on the domestic context . . ${ }^{16}$ (emphasis added)

\footnotetext{
${ }^{12}$ Note also the use of Article 9 in tandem with Article 11 - see eg The Moscow Branch of the Salvation Army v Russia App. No. 72881/01 5 October 2006. Issues of religion may also arise under Article 8 and Article 14 (freedom from discrimination in relation to ECHR rights) and Article 2 of the First Protocol (education).

${ }^{13}$ For recent commentary on the application of the Margin of Appreciation by the Strasbourg institutions see eg Y Arai-Takahashi, The Margin of Appreciation Doctrine and the Principle of Proportionality in the Jurisprudence of the ECHR (Intersentia Oxford 2002); H Yourow The Margin of Appreciation in the Dynamics of European Human Rights Jurisprudence (Kluwer The Hague 1996); M Hutchinson "The Margin of Appreciation Doctrine in the European Court of Human Rights" (1999) 48 ICLQ 638; J Sweeney "Margins of Appreciation: Cultural Relativity and the European Court of Human Right in the Post Cold War Era" (2005) 54 ICLQ 459.

${ }^{14}$ Handyside $v$ UK (1976) 1 EHRR 737 para 48.

${ }^{15}$ Şahin (n 11) para 109. See eg Wingrove v UK (1996) 24 EHRR 1 para 58; Kokkinakis v Greece (1993) 17 EHRR 397 para 47.

${ }^{16}$ Şahin (n 11) para 109.
} 
The width of the margin afforded depends very much on the subject matter of the right in question: the margin granted to states when restricting political or journalistic "public interest" expression (under Article 10) or consensual homosexual conduct in private (under Article 8) has been much narrower (and hence the intensity of scrutiny and level of protection afforded by the Court has been higher) than in cases involving religious manifestation and expression (under both Articles 9 and 10). ${ }^{17}$

A good illustration of the differing levels of protection afforded to political and religious expression can be seen in the outwardly similar cases of VgT Verein Gegen Tierfabriken $v$ Switzerland ${ }^{18}$ and Murphy $v$ Ireland. ${ }^{19}$ Both cases concerned blanket bans on forms of broadcast advertising. In $\operatorname{Vg} T$ the Court held that a prohibition on broadcast political advertising under Swiss law constituted a breach of the applicant organisation's Article 10 rights. The ban was designed to prevent wealthy organisations from buying up large slots of airtime and dominating the airwaves with their own political messages. VgT, a small charitable group campaigning against factory farming, was patently not such an organisation, and yet still had been caught by the ban. The Court held, therefore, that it was a disproportionate interference with VgT's Article 10 rights; the reasons given were not "relevant and sufficient". Murphy concerned a prohibition on broadcast religious advertising, designed to protect religious harmony and avoid benefiting powerful religious groups. Even though the applicant's message was "innocuous and ... informational" 20 and he was not part of such a powerful group the Court found there to be no violation. The Court expressly distinguished $\operatorname{VgT}$ on the grounds that the type of expression required that a greater margin of appreciation be afforded to the state:

[whilst there was] little scope ... for restrictions on political speech or on debate of questions of public interest . . . a wider margin of appreciation [was] generally available ... when regulating freedom of expression in areas liable to offend intimate personal convictions within the sphere of morals or, especially, religion . . . what [was] likely to cause substantial offence to persons of a particular religious persuasion will vary significantly from time to time and from place to place, especially in an era characterised by an ever growing array of faiths and denominations. ${ }^{21}$

The rationale behind this difference of approach appears to lie in the relative instrumental value of the rights in question. ${ }^{22}$ Freedom of political (and journalistic) speech is vital to the democratic process which is central to the ethos of the Convention. $^{23}$ The goal of securing effective representative democracy is served by having a strong protection for public interest "political" expression. The Court has

\footnotetext{
${ }^{17}$ There are difficult questions, beyond the scope of this paper, concerning what constitutes "political" and "religious". In Şahin (n 11) it was noted that the wearing of the headscarf in Turkey had taken on a "political significance ... in recent years" para 115. See M Evans "Religious liberty and international law in Europe" (CUP Cambridge 1997) 284-6.

18 (2002) 34 EHRR 10. One might also contrast eg Wingrove (n 15) and Jersild v Denmark (1994) 19 EHRR 1.

${ }^{19}$ (2004) 38 EHRR 13.

${ }^{20}$ Ibid para 37.

${ }^{21}$ Ibid para 67.

${ }^{22}$ See A Geddis "You Can't Say "God" on the Radio: Freedom of Expression, Religious Advertising and the Broadcast Media after Murphy v Ireland" (2004) 2 European Human Rights Law Review 181.

${ }^{23}$ For discussion of the various philosophical justifications of freedom of expression that have been advanced see E Barendt Freedom of Speech (OUP Oxford 2005) Ch 1.
} 
stated on numerous occasions that the "freedom of political debate is at the very core of the concept of democratic society which prevails throughout the Convention". ${ }^{24}$ On this issue there is stated to be a pan-European consensus.

The value of religious expression and manifestation is less obvious. It apparently produces less in the way of overall societal benefit; it primarily benefits the individual who engages in the religious activity. It is perhaps because of this absence of an obvious "externalised benefit for society as a whole", that there exists across the European continent no "uniform conception of the importance of the significance of religion in society" which in turn justifies the wider margin of appreciation. ${ }^{25}$

It may be legitimate to distinguish between religious and political expression and grant states varying margins of appreciation accordingly, as was done in Murphy and $V g T$. Freedom of expression is primarily about communication. It may be justifiable to rank the different modalities of communication that can be brought under the Article 10 umbrella according to their contribution to societal good. Freedom of expression is a sine qua non of representative democracy. ${ }^{26}$ It fosters ulterior ends, for example, influencing public opinion or garnering political support so as to secure votes and thus political power, or to reveal the inadequacies of, or corruption within, government. It is therefore at least arguable that it is legitimate to give political speech enhanced protection over and above other forms of expression. ${ }^{27}$

The right to manifest religious belief, on the other hand, is not really about the communication of ideas (to facilitate the furtherance of the general good or otherwise). It is about enabling the right holder to exercise her choice to perform what she sincerely believes to be her divinely ordained duty. ${ }^{28}$ Expression may be critical to the attainment of ulterior objectives, but manifestation of religion is the end itself. It is the manifestation that counts - not any ulterior benefit that may be derived from it. Decreasing the level of protection because of the absence of an obvious societal good to be derived would seem to have the result of disproportionately devaluing the right in its own terms.

Another interesting comparison between the widths of margins accorded might be drawn with cases concerning the criminalizing of consensual homosexual behaviour in private. In Dudgeon $v U K$ it was held that the Northern Irish law criminalizing homosexual conduct breached the right to respect for a private and family life protected by Article $8 \mathrm{ECHR}^{29}$ This was notwithstanding the fact that many in Northern Ireland were in favour of the ban in order to protect the moral fabric of

\footnotetext{
${ }^{24}$ See eg Lingens v Austria (1986) 8 EHRR 407; Castells v Spain (1992) 14 EHRR 445; United Communist Party of Turkey v Turkey (1998) 26 EHRR 121; The Moscow Branch of the Salvation Army v Russia (n 12) para 60; A Mowbray "The Role of the European Court of Human Rights in the Promotion of Democracy" (1999) Public Law 703.

${ }^{25}$ A Geddis (n 22) 189. These issues are considered more fully in Part III.

${ }^{26} \mathrm{~J}$ Raz argues in The Morality of Freedom (Clarendon Press Oxford 1986) 261 that the "argument for the entrenchment of liberal constitutional rights derives . . . from several sources . . . the interest of the right holder itself . . . is insufficient to justify that degree of protection. It gets it because it is instrumentally useful to the preservation of a certain political culture, to the protection of various public or even collective goals".

${ }^{27}$ See the debate between P Mahoney "Universality versus Subsidiarity in Strasbourg Case Law on Free Speech: Explaining Some Recent Judgments" (1997) 4 European Human Rights Law Review 364 and Lord Lester of Herne Hill "Universality versus Subsidiarity: A Reply" (1998) 1 European Human Rights Law Review 73.

${ }^{28}$ See Part III below. Some religions, eg Jehovah's Witnesses, require believers to bear of witness, teach and preach - but this is due to perceived religious duty to "try and convince one's neighbour". See Kokkinakis v Greece (n 15) at para 31.

${ }^{29}$ (1982) 4 EHRR 149.
} 
society. ${ }^{30}$ This lack of consensus on an issue where restrictions on conduct were being imposed in order to protect morals would seem to invite the granting of a wide margin of appreciation. However the Court held that since the case concerned a "most intimate aspect of private life" there had to "exist particularly serious reasons before interferences by public authorities could be legitimate". 31 The margin of appreciation afforded was consequently very narrow. This approach reflects the Millian principle that:

the only purpose for which power can be rightfully exercised over any member of a civilised community, against his will, is to prevent harm to others. $\mathrm{He}$ cannot rightfully be compelled to do or to forbear because it will be better for him to do so, because it will make him happier, because in the opinion of others, to do so would be wise, or even right. ${ }^{32}$

Thus conduct in private receives a high level of protection as it is far less likely to cause harm (however defined) than conduct in public.

The right to religious freedom under Article 9 ECHR is phrased as follows:

1.Everyone has the right to freedom of thought, conscience and religion; this right includes freedom to change his religion or belief and freedom, either alone or in community with others and in public or private, to manifest his religion or belief, in worship, teaching, practice and observance.

2. Freedom to manifest one's religion or beliefs shall be subject only to such limitations as are prescribed by law, and are necessary in a democratic society in the interests of public safety, for the protection of public order, health or morals, or for the protection of the rights and freedoms of others. ${ }^{33}$

Under the two paragraph structure freedom of thought, conscience and religion, the forum internum (the internal sphere), has absolute protection. It is only the manifestation of religion or belief that may be restricted under the second paragraph: thus privately held beliefs are untouchable but once they emerge into the open, once they become manifest, the state is entitled to impose restrictions (as long as they pursue a legitimate aim, are "prescribed by law" and are "necessary in a democratic society"). A religious adherent who believes that she must manifest her belief when entering public space will inevitably run the risk that her conduct will impact more heavily on others (and arguably cause some kind of "harm") than conduct which is kept entirely within the private domain. ${ }^{34}$

\footnotetext{
${ }^{30}$ Ibid paras 56-7.

${ }^{31}$ Ibid para 52. See also Norris v Ireland (1991) 13 EHRR 186.

32 JS Mill On Liberty (1859) in On Liberty and other writings (CUP Cambridge 1989) ed S Collini 13.

${ }^{33}$ On Article 9 generally see C Evans Freedom of Religion Under the European Convention on Human Rights (OUP Oxford 2001) and M Evans (n 17) 10-12. See also S Langlaude "Indoctrination, Secularism, Religious Liberty and the ECHR" (2006) 55 ICLQ 929. For historical background to the Article see C Evans ch 3 and M Evans ch 10.

${ }^{34}$ It as been argued that this split between the forum internum and the forum externum has the effect of favouring post-Reformation Christianity which emphasises more the internal holding of faith than outward display of it; one of the central issues of the European Reformation was whether justification could be sola fide, by faith alone, (Martin Luther's position) or whether good works were necessary: see P Collinson The Reformation (Phoenix London 2005) 47-9. Other faiths, by contrast, place much more weight on outward observance: see C Evans (n 33) 202; PW Edge and G Harvey (eds) Law and Religion in Contemporary Society (Ashgate Aldershot 2000) 7-8.
} 
In a sense, therefore, the believer manifesting her religion by, for instance, wearing a particular garment in public space has the worst of both worlds when it comes to the role of the margin of appreciation in the adjudication of her rights. In comparison to public interest expression religious manifestation plays a poor second fiddle because it is not central to the effective operation of political democracy; and in comparison to intimate sexual behaviour in private, notwithstanding the fact that many may object to it on the grounds of morals, religious manifestation receives a very low level protection because of its public dimension - because the manifestation is, by definition, visible in public space.

\section{PHILOSOPHICAL UNDERPINNINGS OF RELIGIOUS FREEDOM}

In order to understand why the right to manifest and express religious belief apparently receives inferior protection from the Court it is necessary to consider, briefly, the philosophical underpinnings of the right: why is it considered to be worthy of elevation to the hallowed status of a human right in the first place? The European Court itself has stressed its importance repeatedly and has given some indication of the reasons for its being valued:

freedom of thought, conscience and religion is one of the foundations of a 'democratic society' ... one of the most vital elements that go to make up the identity of believers and their conception of life, but it is also a precious asset for atheists, agnostics, sceptics and the unconcerned. The pluralism indissociable from a democratic society, which has been dearly won over the centuries, depends on it. ${ }^{35}$

Religious freedom has a long historical pedigree, being one of the first of the commonly acknowledged human rights to be recognised and justified philosophically. ${ }^{36}$ Despite its heritage, however, the underlying philosophical justification for the right to religious freedom remains somewhat vague. ${ }^{3}$

From the broad liberal perspective ${ }^{38}$ the justifications for religious freedom may loosely be grouped into two camps: instrumental justifications that see religious freedom as serving some ulterior social end; and deontological justifications that focus on the autonomy of the individual.

Perhaps the main instrumental argument in favour of religious freedom, or at least toleration, is that without it there would be persecution, social unrest and conflict, leading in extreme cases to war. ${ }^{39}$ In his Letter Concerning Toleration John Locke said that:

It is not the diversity of opinions (which cannot be avoided), but the refusal of toleration to those that are of different opinions (which might have been granted) that

\footnotetext{
${ }^{35}$ The quote originates in Kokkinakis (n 15) para 31 and has been intoned by the Court in virtually every Article 9 case.

36 See eg John Locke Letter Concerning Toleration (1685) in David Wootton (ed) John Locke Political Writings (Penguin London 1993) 390 .

${ }^{37}$ The same point might be made about human rights generally. See C Gearty Can Human Rights Survive (CUP Cambridge 2006) especially ch 2.

${ }^{38}$ As opposed to justifications based on religious perspectives on which see eg $\mathrm{R}$ Ahdar and I Leigh Religious Freedom in the Liberal State (OUP Oxford 2005) ch 1; C Evans (n 33) 25-8.

${ }^{39}$ For example the Wars of Religion following the Reformation in Europe.
} 
has produced all the bustles and wars that have been in the Christian world, on account of religion. ${ }^{40}$

In modern times similar justifications have been advanced. For example the preamble to the United Nations Declaration on the Elimination of All Forms of Intolerance and of Discrimination Based on Religion and Belief states:

that the disregard and infringement of human rights and fundamental freedoms, in particular of the right to freedom of thought, conscience, religion or whatever belief, have brought, directly or indirectly, wars and great suffering to mankind ... ${ }^{41}$

Such instrumental justifications, whilst having a strong intuitive appeal, are subject to limitations. Foremost among these is that, in some situations, it may well be the case that the social end in view is best achieved not by permitting religious freedom but by suppression. For example in a society with a small minority of unpopular, though pacifistic, religious dissenters the interests of social harmony may best be served by the forceful imposition of single national religion and the repression of those dissenters. ${ }^{42}$ Tying the reason for protecting religious freedom to some ulterior end risks the possibility that that end could be better achieved by the abolition of religious freedom.

The main deontological justifications advanced by modern liberal thinkers for freedom of religion centre on the notions of human dignity and personal identity which can only be assured by a recognition of personal autonomy. ${ }^{43}$ Joseph Raz explains the idea in The Morality of Freedom:

The ruling idea behind the ideal of personal autonomy is that people should make their own lives. The autonomous person is a (part) author of his life. The ideal of personal autonomy is the vision of people controlling, to some, degree, their own destiny, fashioning it through successive decisions throughout their lives ...

Autonomy is opposed to a life of coerced choices. It contrasts with a life of no choices, or of drifting through life without ever exercising one's capacity to choose. ${ }^{44}$

In somewhat different terms Ronald Dworkin, in Taking Rights Seriously, explains:

Government must treat those whom it governs with concern, that is, as human beings who are capable of suffering and frustration, and with respect, that is human beings who are capable of forming and acting on intelligent conceptions of how their lives should be lived. ${ }^{45}$

In the context of religious dress, therefore, and assuming the absence of coercion, the decision to follow a certain religious path and manifest it through clothing reflects the

\footnotetext{
${ }^{40}$ J Locke (n 36) 431.

${ }^{41}$ G.A. Res. 36/55, U.N. GAOR, Supp. (No.51) 171, U.N. Doc. A/36/684 (1981).

${ }^{42} \mathrm{R}$ Ahdar and I Leigh (n 38) 53 - 4; C Evans (n 33) 23.

43 Such arguments have been offered as the basis for human rights generally. See eg R Dworkin Taking Rights Seriously (Duckworth London 1977); J Rawls A Theory of Justice (Clarendon Press Oxford 1999); J Raz (n 26); J Griffin "First Steps in an Account of Human Rights" 9 European Journal of Philosophy (2001) 306; D Feldman Civil Liberties and Human Rights in England and Wales (OUP Oxford 2002); R Ahdar and I Leigh (n 38) 57-60; C Evans (n 33) 29-33.

44 J Raz (n 26) 369-71; R Dworkin (n 43); J Rawls (n 43) 17-22.

${ }^{45}$ R Dworkin (n 43) 272.
} 
autonomous choice of the adherent. The woman claiming the right to wear the headscarf is exercising her autonomy.

A necessary concomitant of a commitment to personal autonomy is some form of value pluralism. For autonomy, freedom to exercise choice, to be meaningful there must exist a plurality of life paths from which to choose. As Raz explains:

Autonomy is exercised through choice, and choice requires a variety of options to choose from. To satisfy the conditions of the adequacy of the range of options the options available must differ in respects which may rationally affect choice. If all the choices in life are like the choice between two identical-looking cherries from a fruit bowl, then that life is not autonomous. Choices are guided by reasons and to present the chooser with an adequate variety there must be a difference between the reasons for the different options . . . valuing autonomy leads to the endorsement of moral pluralism. ${ }^{46}$

Indeed a necessary consequence of autonomy is that people will pursue a variety of paths. Inevitably these paths will sometimes conflict and yet still be viewed as valuable as deriving from the free choices of rational agents. ${ }^{47}$

[Conflict] is endemic to value pluralism in all its forms. Belief in value pluralism is the view that many different activities and forms of life which are incompatible are [nevertheless] valuable. ${ }^{48}$

Ronald Dworkin says that:

[g]overnment must not only treat people with concern and respect, but with equal concern and respect ... It must not constrain liberty on the ground that one citizen's conception of the good life of one group is nobler or superior to another's. ${ }^{49}$

Allied with these notions in liberal thought is that of state neutrality - that the state should remain broadly neutral with regard to different views of the good life or, more particularly, the promotion of one religious faith over another. ${ }^{50}$ Religions (and their associated practices) are but one choice available to autonomous individuals and the state's role is to provide a neutral framework within which choice may be exercised. ${ }^{51}$

The principle of autonomy holds attractions as a philosophical basis for religious freedom. ${ }^{52}$ It avoids the problems associated with instrumental justifications outlined above. It recognises the equal worth and dignity of individuals and avoids the overriding of human dignity and personal identity for purely instrumental causes.

\footnotetext{
${ }^{46}$ J Raz (n 26) 398-9.

${ }^{47}$ Ibid 395-9.

${ }^{48} \mathrm{~J}$ Raz "Multiculturalism: A Liberal Perspective" at 164 in Ethics in the Public Domain (OUP Oxford 1994).

${ }^{49} \mathrm{R}$ Dworkin (n 43) $272-3$.

${ }^{50}$ R Dworkin "Liberalism" in S Hampshire (ed) Public and Private Morality (CUP Cambridge 1977) ch 6 127; J Raz (n 26) 110. There is a debate between proponents of perfectionist and anti-perfectionist or "procedural" liberal thought - those who believe the state should remain strictly neutral as between different conceptions of the good (Rawls (n 43), Dworkin (n 43) ) and those who consider that the state may endorse certain values as good (Raz (n 43), W A Galston Liberal Purposes (CUP Cambridge 1991) ). See R Adhar and I Leigh (n 38) 42-3.

${ }^{51}$ The Court's case law reflects the liberal principle of neutrality; the state has a duty to remain neutral and impartial and is not entitled to assess the legitimacy of religious beliefs or their means of expression: see eg Hassan and Chaush v Bulgaria (2000) 30 EHRR 50 para 78.

${ }^{52}$ C Evans (n 33) 32-3.
} 
However it also gives rise to several problems. Firstly, if the basis for the right to religious freedom is respect for the individual autonomy of the believer, respect for the individual's freely chosen life path, this raises the inevitable question of why that particular choice be given more weight or protection than any other freely chosen life path? What distinguishes a choice to devote life to the pursuit of a particular religious path, along with the dress requirements that that choice entails, to another's to pursue a life of, say, literature or music or sport?

Religion is no longer special or distinctive but is simply lumped into a category along with other things important to personal identity such as political affiliations, racial or ethnic background, profession, occupation or marital status. . if freedom of choice is paramount, the object of that choice - religion, political cause, music, sport or anything else - is irrelevant. It is the process of choice that must be protected. ${ }^{53}$

The right to religious freedom thus tends to become subsumed into a general homogenised protection of individual autonomy. Malcolm Evans puts it thus:

Quite what forms the philosophical basis upon which contemporary human rights thinking is based is, to say the least, vague. Nevertheless the prevailing view is that human rights are essentially 'secular' in nature and whilst freedom of religion is certainly accepted as a human right its demands are no more pressing than other rights within the secularised canon. ${ }^{54}$

Conor Gearty explains in characteristically pithy terms:

In the progressive secular circles that make today's philosophical weather, religion is like cross-dressing, anal intercourse or learning ancient Greek, something you are perfectly entitled to do as long as it makes you feel better and does not unduly interfere with anyone else's personal life projects. ${ }^{55}$

There is another problem with identifying autonomy as the philosophical basis of the right to religious freedom. As far as the believer herself is concerned it may be more appropriate to say not that she chooses her faith but that her faith, or God, chooses her. ${ }^{56}$ So it becomes not a question of exercising individual rational decision making power between a plurality of competing paths but rather a matter of eternal, absolute, divinely ordained duty. ${ }^{57}$ In the context of female Muslim dress, for instance, the Qur'an prescribes that which should be worn by believers in the following terms:

\footnotetext{
${ }^{53}$ R Ahdar and I Leigh (n 38) 60-1.

${ }^{54}$ M Evans "Religion law and human rights: locating the debate" in P W Edge and G Harvey (n 34) 182. See also F Raday (n 10) 663.

55 C Gearty "The Holism of Human Rights: Linking Religion Ethics and Public Life" (2004) 6 European Human Rights Law Review 605. See R Ahdar and I Leigh (n 38) 60-4.

${ }^{56}$ See R Ahdar and I Leigh (n 38) at 62-3; J Garvey "Free Exercise and the Values of Religious Liberty" (1986) Connecticut Law Review 779, 791; P W Edge "Religious rights and choice under the European Convention on Human Rights" [2000] 3 Web Journal of Current Legal Issues. This point was made by the government before the Chamber in Şahin v Turkey (2005) 41 EHRR 8 para 92.

${ }^{57}$ For example the literal meaning of "Islam" is "surrender [to the will of God]". See K Armstrong The Battle for God (Harper Collins London 2000) 375. Some commentators have argued that the whole notion of individual rights sits uneasily with some religious cultures eg the Islamic concept of ummah or community raises potential difficulties for Muslims bringing individual human rights claims; see A Bradney "Law and Religion in Great Britain at the End of the Second Christian Millennium" in P W Edge and G Harvey (n 34) $24-6$.
} 
And tell believing women that they should lower their glances, guard their private parts, and not display their charms beyond what [it is acceptable] to reveal; they should let their headscarves fall to cover their necklines and not reveal their charms except to their husbands, their fathers, their husbands' fathers, their sons . . ${ }^{58}$

and

Prophet, tell your wives, your daughters, and women believers to make their outer garments hang low over them so as to be recognised and not insulted. ${ }^{59}$

A Hadith $^{60}$ requires that once a woman reaches the age of menstruation no more should be revealed of her body than her face and her hands. ${ }^{61}$ Thus autonomy, individual choice, has very little to do with it.

For several reasons, therefore, there are significant problems with identifying a coherent and subjectively appropriate philosophical rationale for the right to religious freedom. It is submitted that this uncertainty lies at the heart of the explanation for the weak protection given to religion by the Court and that it is via the margin of appreciation that these uncertainties reveal themselves in its case law. The Court's inability to pin down quite why religious freedom is valued, the absence of a clearly defined and universally accepted rationale, ${ }^{62}$ has contributed to the adoption of the margin of appreciation as a significant adjudicative tool in this area. As has been seen, justifications for religious freedom based on autonomy lead to problems: in particular an inability easily to rank one life path above another and the fact that it fits uneasily with the view of religious adherents themselves. This creates space for the margin of appreciation. By contrast, where the right in question makes a tangible contribution to societal good, or is vital to dignity and autonomy and its exercise remains wholly within the private sphere, the right is accorded "added value" lifting it above the mêlée of other autonomy fostering entitlements.

There is a further fundamental problem with the granting of a margin of appreciation to states on the basis of there being an absence of a pan-European consensus on religious issues. ${ }^{63}$ For this argument tends to undercut the (albeit unsatisfactory) rationale for protecting the right to manifest religious belief in the first place. The predominant justification for the very existence of the right is to enable the right holder to depart from the consensus, to pursue his or her own path. If there were an international consensus on this question of religion, if there were a single European faith akin to pre-Reformation Christendom to whose creed and liturgy everyone adhered, there would be no need for the religious right. It is only because of diversity, because, indeed, of that pluralism so central to the whole scheme of the Convention, that the right is necessary and important. And yet the margin of appreciation is invoked, and its use is legitimised, precisely because of the very absence of consensus that makes the right so vital.

\footnotetext{
${ }^{58}$ Chapter 24 (the Light) Verse 31.

${ }^{59}$ Chapter 33 (the Clans) Verse 59. There are many translations of these verses. The above are taken from the that of M A S Abdel Haleem (OUP Oxford 2004).

${ }^{60}$ Documented reports of the sayings of the Prophet Muhammad that do not appear in the Qur'an but were recorded for posterity by his close companions and family.

${ }^{61}$ Sunan Adbu-Dawud: Book 32 Hadith 4092. Beliefs as to what these verses actually require by way of dress differ widely within Islam. See eg the judgment of Brooke $\mathrm{LJ}$ in $R$ (on the application of Begum) v Denbigh High School Governors [2005] EWCA Civ 199; [2005] 1 WLR 3372 paras 31-48.

${ }^{62}$ Note the Court's vague pronouncements on pluralism and the importance of religion to the individual believer (n 35).

${ }^{63}$ See n 16 and n 21.
} 


\section{RELIGIOUS DRESS CASES}

The consequences of the doctrinal uncertainties and consequent weakened protection sketched out above have nowhere been more evident than in several applications to the Court and Commission by Muslim women claiming the right to manifest their religious belief through dress.

In Karaduman $v$ Turkey a student who had successfully completed her studies at Ankara University was not allowed to graduate because she refused to submit a photograph of herself bare-headed. Her claim of a breach of Article 9 was rejected by the Commission which found there to have been no interference with her Article 9 rights. $^{64}$ In the admissibility decision of Dahlab $v$ Switzerland a primary school teacher was dismissed because she insisted on wearing a Muslim headscarf. The Court, having regard to the denominational neutrality of the Swiss education system, the "tender age" of the pupils concerned and the margin of appreciation in matters of religion, found that the action was not a disproportionate interference. The Court said that:

it cannot be denied outright that the wearing of a headscarf might have some kind of proselytising effect, seeing that it appears to be imposed on women by a precept which is laid down in the Koran and which . . . is hard to square with the principle of gender equality. It therefore appears difficult to reconcile the wearing of an Islamic headscarf with the message of tolerance, respect for others and, above all, equality and non-discrimination that all teachers in a democratic society must convey to their pupils. $^{65}$

The case of Refah Partisi (The Welfare Party) $v$ Turkey ${ }^{66}$ did not directly concern religious dress but rather the banning of an Islamic political party by the Turkish authorities on the ground that it had become a "centre of activities contrary to the principles of secularism". ${ }^{67}$ The Court found there to have been no violation of Article 11 of the Convention. The political program which it found to be attributable to Refah, if it were to be put into effect, could have the consequence of destroying democracy itself:

No one must be authorised to rely on the Convention's provisions in order to weaken or destroy the ideals of democratic society. Pluralism and democracy are based on a compromise that requires various concessions by individuals or groups ... who must sometimes agree to limit some of the freedoms they enjoy in order to guarantee greater stability of the country as a whole. ${ }^{68}$

\footnotetext{
${ }^{64}$ App No 16278/90 May 1993, 74 DR 93. For comment and comparison with Şahin see H Gilbert "Redefining Manifestation of Belief in Leyla Şahin v Turkey" (2006) 3 European Human Rights Law Review 308.

${ }^{65}$ Dahlab (n 5) at 15. For comment on both Karaduman and Dahlab see D Lyon and D Spini (n 10).

${ }^{66}$ (2003) 37 EHRR 1. For comment see P Cumper "Europe, Islam and Democracy - Balancing Religious and Secular Values under the European Convention on Human Rights" (2003/4) 3 European Yearbook of Minority Issues 163

${ }^{67}$ Refah had been elected as the largest party in the Grand National Assembly in 1995. Party members had, inter alia, called for jihad, encouraged the wearing of Islamic headscarves, advocated the introduction of sharia law and a plurality of legal systems.

${ }^{68} \operatorname{Refah}(\mathrm{n} 66)$ para 99.
} 
The Court acknowledged that the principle of secularism was one of the fundamental principles of the Turkish state. ${ }^{69}$ It also reiterated that, in a democratic society, limitations on the manifestation of religion, for instance the wearing of the Islamic headscarf, may be legitimate if necessary to protect the freedoms of others or public order. $^{70}$

The most significant of these cases, from the viewpoint of religious manifestation through dress, has been that of the Leyla Şahin v Turkey. In August 1997 Leyla Şahin, a medical student, enrolled at Istanbul University. In February 1998 the Vice Chancellor of the University issued a circular prohibiting the wearing on campus of the Islamic headscarf and the wearing of beards. ${ }^{71}$ Subsequently Şahin was refused access to lectures and examinations and refused enrolment on account of her wearing an Islamic headscarf. Disciplinary proceedings were brought against her for participating in an unauthorised demonstration against the ban and she was suspended from the university for a semester, although an amnesty was later issued revoking this penalty. Her attempts to have the circular set aside by the Turkish courts failed. In September 1999 she transferred to Vienna University in order to be able to continue her studies.

She applied to the European Court of Human Rights claiming a breach of Article 9. ${ }^{72}$ The Turkish government argued that the headscarf ban in universities was necessary to protect the constitutional values of secularism and gender equality. ${ }^{73}$ The principle of secularism had been stated by the Turkish Constitutional Court to be the guarantor of democratic values, preventing the state from manifesting a preference for a religion, and protecting the individual from arbitrary interference from the state and from pressure from extremist movements. ${ }^{74}$ Following its approach in Refah the Grand Chamber reiterated that constitutionally enshrined secularism was "consistent with the values underpinning the Convention" and was "in harmony with the rule of law ... . respect for human rights . . . [and] necessary to protect the democratic system". An attitude which did not respect that principle would "not necessarily be accepted as being covered by the freedom to manifest one's religion and will not enjoy the protection of Article 9". 75

\footnotetext{
${ }^{69}$ Ibid para 93. The Court cited the Turkish Constitutional Court's strong affirmation of secularism (para 40) and endorsed that court's strong critique of sharia law as incompatible with democracy (para 123).

${ }^{70}$ Ibid para 92.

${ }^{71}$ This was pursuant to a series of judicial decisions of the Turkish Administrative and Constitutional Courts. For comment see Human Rights Watch Briefing Paper "Memorandum to Turkish Government on Human Rights Watch's Concerns with regard to academic Freedom in Higher Education, and Access to Higher Education for Women who Wear the Headscarf' (29 June 2004).

${ }^{72}$ She also claimed breaches of Article 2 of Protocol 1, Article 8, Article 10 and Article 14. For comment see J Marshall "Religious Freedom and Gender Equality" (2006) 69 Modern Law Review 452; S Langlaude (n 33). For comment on the Chamber judgment see D Decker and M Lloyd (2004) 6 European Human Rights Law Review 672; H Gilbert (n 64); Human Rights Watch: Human Rights News "Headscarf Ruling Denies Women Education and Career" (16 November 2005).

${ }^{73}$ Article 2 of the Turkish Constitution states: "The Republic of Turkey is a democratic, secular (laik) and social State based on the rule of law, respectful of human rights in a spirit of social peace ...."

Article 10 states: "All individuals shall be equal before the law without any distinction based on language, race, colour, sex, political opinion, philosophical belief, religion . . . Men and women shall have equal rights. The State shall take action to achieve such equality in practice ..."

${ }^{74}$ Judgment of 7 March 1989 cited in Şahin (n 11) paras 39 and 113. See also the quotes from the Turkish Constitutional Court cited in Refah Partisi (n 69).

${ }^{75}$ Şahin (n 11) para 114.
} 
The Turkish constitutional system also emphasised the rights of women and gender equality. The Grand Chamber stated that:

there must be borne in mind the impact wearing [the headscarf], presented as a compulsory religious duty, may have on those who choose not to wear it . . . the issues at stake include the protection of the 'rights and freedoms of others' and the 'maintenance of public order'. ${ }^{76}$

Imposing these limitations, the Grand Chamber said, could be regarded as meeting a pressing social need by seeking to achieve these aims, for the wearing of the headscarf had taken on a political dimension in recent years. In particular there existed the threat of "extremist political movements" seeking "to impose on society as a whole their religious symbols and conception of society founded on religious precepts." ${ }^{, 77}$ It was legitimate for the state to take a stance against such movements and it was understandable that the university authorities should wish to preserve the pluralist and secular nature of the institution and so "consider it contrary to such values to allow religious attire, including . . . the Islamic headscarf, to be worn". ${ }^{78}$ In matters of religion the state was entitled to a margin of appreciation:

[b]y reason of their direct and continuous contact with the education community the university authorities are in principle better placed than an international court to evaluate local needs and conditions or the requirements of a particular course . . . Having found that the regulations pursued a legitimate aim it [was] not for the Court to apply the criterion of proportionality in a way that would make the notion of the institution's 'internal rules' devoid of purpose. Article 9 [did] not always confer a right to behave in a manner governed by religious belief and [did] not confer on people who [did] so the right to disregard rules that have proved to be justified. ${ }^{79}$

By a majority of sixteen votes to one the Grand Chamber concluded that the measures were a proportionate interference with Leyla Şahin's Article 9 rights. ${ }^{80}$

\section{Margin of Appreciation as Self Denying Ordinance}

The consequence of the use of the margin of appreciation doctrine for Leyla Şahin was critically to diminish the rigour with which the Court addressed the question of whether the state's action was "necessary in a democratic society" in her particular case. Indeed, in the words of the sole dissentient, Judge Tulkens, whilst admittedly the role of the European Court was a "supervisory one" the "European supervision seem[ed] quite simply to be absent from the judgment". ${ }^{81}$ This absence was manifested in various ways. The majority accepted the Turkish government's argument that the ban was necessary in order to protect the constitutional principles of secularism and equality between the sexes. ${ }^{82}$ But there was no evidence that Leyla Şahin herself posed any threat whatsoever to these values. She neither called into

\footnotetext{
${ }^{76}$ Ibid para 115 (quoting paras $107-9$ of the Chamber judgment).

${ }^{77}$ See Refah Partisi (n 66).

${ }^{78}$ Şahin (n 11) paras 115-6

${ }^{79}$ Şahin (n 11) para 121.

${ }^{80}$ The majority also found there to have been no breach of the other Articles. The only one considered in any detail was Article 2 of the First Protocol (n 11) paras 134-142.

${ }^{81}$ Şahin (n 11) Judge Tulkens' dissent para 3. See S Langlaude (n 33) at 936-7.

${ }^{82}$ Translated into Article 9(2) terms it was held to be necessary in order to protect the "rights and freedoms of others" and "public order".
} 
question the principle of secularism ${ }^{83}$ nor did she wear the headscarf in order to "exert pressure, to provoke a reaction, to proselytise . . . to spread propaganda or to undermine the convictions of others". There was no evidence of disruption to teaching or the everyday life of the University, or of any disorderly conduct. ${ }^{84}$ As Judge Tulkens said:

Only indisputable facts and reasons whose legitimacy is beyond doubt - not mere worries or fears - are capable of satisfying that requirement and justifying interference with a right guaranteed by the Convention ... [m]ere affirmations do not suffice: they must be supported by concrete examples. Such examples do not appear to have been forthcoming in [this] case. ${ }^{85}$

The majority stressed the impact that the wearing of the headscarf, "presented as a compulsory religious duty may have on those who choose not to wear it". ${ }^{86}$ But Judge Tulkens pointed out that in other fields the mere causing of offence has not been regarded as a good enough reason to limit expression. For example in the sphere of freedom of expression "the Court has never accepted that the interference . . . can be justified by the fact that the ideas or views are not shared by everyone and may even offend some people". ${ }^{87}$ And again, "the judgment fail[ed] to provide any concrete example" of the type of pressure that, it was alleged, was being imposed by "extremist political movements" and that the ban was intended to counter. The result of the majority's invocation of the margin of appreciation was that Leyla Şahin's personal interest in exercising her right to manifest her religion by an external symbol was "wholly . . . absorbed by the public interest in fighting extremism". 88 The argument centred not on the individual's behaviour but on the reactions of others what those around them would read into her clothes.

Similar criticisms may be made of the Court's lack of rigour in its reasoning in respect of the need to protect gender equality. In particular the Court accepted that it may be necessary to protect the applicant herself from being forced to wear the headscarf. But, as the dissentient judge pointed out, this was a "young adult university student - and there is nothing to suggest that she is not telling the truth that she wore the headscarf of her own free will". How could the "principle of sexual equality justify prohibiting a woman from following a practice which, in the absence of proof to the contrary, she must be taken to have freely adopted. Equality and nondiscrimination are subjective rights which must remain under the control of those who are entitled to benefit from them". ${ }^{89}$ Certainly, if it were shown that pressure was being brought to bear from families, or religious elites, this would have constituted a

\footnotetext{
${ }^{83}$ Şahin (n 11) Judge Tulkens' dissent para 7. She also contrasted the position of students (in the instant case) with that of teachers (eg in Dahlab n 5): "While the principle of secularism requires education to be provided without any manifestation of religion and while it has to be compulsory for teachers and all public servants, as they have voluntarily taken up their posts in a neutral environment, the position of pupils and students seems to me to be different." See C Langenfeld and S Mohsen "Germany: the Headscarf Teacher case"(2005) 3 International Journal of Constitutional Law 86, 92-3 commenting on the German position.

${ }^{84}$ Şahin (n 11) (Judge Tulkens) para 8. See G Davies (n 10) 520.

${ }^{85}$ Şahin (n 11) (Judge Tulkens) para 5.

${ }^{86}$ Şahin (n 11) (majority) para 115.

87 Şahin (n 11) (Judge Tulkens) para 9. See also Baroness Hale's speech in Begum (n 5) para 96, G Davies (n 10) 520. Otto-Preminger Institute v Austria (1994) 19 EHRR 34 would seem to be an exception to this.

${ }^{88}$ Şahin (n 11) (Judge Tulkens) para 10.

${ }^{89}$ Ibid para 11.
} 
strong argument on behalf of restriction. Indeed the principle of autonomy, the individual's freedom to choose not to wear the headscarf, would require this. Furthermore it is arguable that under Article 9 itself the state would be under a positive duty to protect girls and women from such coercion from private actors. ${ }^{90}$

But the profound intrusion of the margin of appreciation resulted in the Court's reasoning becoming impossibly blunt: no allowance was made at all for the individual circumstances or behaviour of the applicant; a wholesale ban was accepted as a proportionate interference virtually without question; the state's word that there existed a threat was accepted without evidence. It may be entirely legitimate to place restrictions on religious dress in universities - but more is needed by way of justification than mere assertion.

Furthermore it was open for the Court to say that Leyla Şahin's Article 9 rights had been breached without finding that in all circumstances to ban the headscarf would constitute a breach. For example in Kokkinakis the Court held that it was permissible to have a law criminalising proselytism in order to protect vulnerable individuals from undue pressure from zealots yet held that the prosecution of the particular individual in the case constituted a breach of Article 9 because he had not been shown to have tried to convert "his neighbour by improper means". 91 For sure this would have caused problems for the state in Şahin. Indeed the problems of creating a rule that was sufficiently nuanced to distinguish between those wearing the headscarf as a peaceful manifestation of genuine belief and those acting in a threatening way, pursuing anti-democratic extremist programmes, or being coerced by fathers or brothers, may in fact have proved insurmountable. ${ }^{92}$ But if it is sympathy with the state's difficulties in drafting a sufficiently finely tailored rule that does explain the Court's decision it ought to have said so. ${ }^{93}$

The recent case of The Moscow Branch of the Salvation Army $v$ Russia ${ }^{94}$ at first sight seems to stand in contrast to Şahin. The European Court found a breach of the Salvation Army's religious rights on account of the failure of the Moscow authorities to recognise its legal status as a religious organisation. ${ }^{95}$ Closer inspection, however, serves to emphasise the distinction the Court draws between individual(ised) religious manifestation rights and those expressive rights that it deems to be more socially valuable, rights perceived as serving a useful role in the upkeep of a healthy democratic polity.

The applicants claimed a breach of Articles 9 and 11 in tandem. The Court stated that since religious communities traditionally exist in the form of organised structures, Article 9 had to be interpreted in the light of Article $11 .{ }^{96}$ In a revealing passage the Court continued:

\footnotetext{
${ }^{90}$ See eg $A v U K$ (1998) 27 EHRR 611; $X$ and $Y v$ Netherlands (1985) 24 EHRR $188 . \quad$ On positive obligations generally see A Mowbray The Development of Positive Obligations under the European Convention on Human Rights (Hart Oxford 2004).

${ }^{91}$ Kokkinakis (n 15) para 48-9.

${ }^{92}$ Arguments of this kind were influential in the Court's decision in Murphy (n 19) paras 77-8.

${ }^{93}$ See P Sales and B Hooper "Proportionality and the Form of Law" 119 (2003) Law Quarterly Review 426.

${ }^{94}$ App No 72881/01 5 October 2006 (Chamber: First Section).

${ }^{95}$ The grounds for the refusal changed throughout the course of the domestic proceedings. They included: an insufficient number of founding members and the absence of documents showing their residence in Russia; the paramilitary structure of the organisation; inconsistent indication of the organisation's religious affiliation.

${ }^{96}$ Salvation Army (n 94) para 58.
} 
While in the context of Article 11 the Court has often referred to the essential role played by political parties in ensuring pluralism and democracy, associations formed for other purposes, including those proclaiming or teaching religion, are also important to the proper functioning of democracy. For pluralism is also built on the genuine recognition of, and respect for, diversity and the dynamics of cultural traditions, ethnic and cultural identities, religious beliefs, artistic, literary and socioeconomic ideas and concepts. The harmonious interaction of persons and groups with varied identities is essential for achieving social cohesion. It is only natural that, where a civil society functions in a healthy manner, the participation of citizens in the democratic process is to a large extent achieved through belonging to associations in which they may integrate with each other and pursue common objectives collectively. (emphasis added) ${ }^{97}$

This hitching of Article 9 to Article 11 seems to have resulted in the Court adopting a much stricter approach to the state's interference; the extremely wide margin of appreciation that the Court so readily granted in Şahin was dramatically narrowed:

The exceptions to the rule of freedom of association are to be construed strictly and only convincing and compelling reasons can justify restrictions on that freedom. In determining whether a necessity within the meaning of paragraph 2 of these Convention provisions exists, the States have only a limited margin of appreciation, which goes hand in hand with rigorous European supervision . . . (emphasis added) ${ }^{98}$

As a result the Court held that the actions of the Russian authorities were not justified; there was found to be a violation of Article 11 "read in the light of Article 9".

Article 11 is a right vital to the "proper functioning of democracy". The Court perceives clear benefits deriving from the popular participation in civic associations and societies whose existence is central to democratic pluralist society. The conjoining of the religious with the associative right seems, therefore, to have been an important component in the success of the Salvation Army before the Court. ${ }^{99}$

\section{NOT PLAYING BY THE RULES?}

The impression created by the religious dress cases is that "Europe has tied itself to principles that it does not believe in"; ${ }^{100}$ that they are tangential, and sometimes antithetical, to the core values of personal autonomy and liberal democracy within an essentially secular constitution. This, it is submitted, is the core explanation for the varying margins of appreciation afforded to states in cases of manifestation and expression of religion as opposed to political and journalistic expression, association and matters of intimate personal sexuality. The latter are close to the underpinning European secular human rights values; the former are not.

Now all this might all be explicable in terms of the internal logic of human rights theory; it may even be justifiable. But from the standpoint of an individual bringing a claim to be allowed to manifest her religious belief by wearing a headscarf, a practice

\footnotetext{
${ }^{97}$ Ibid para 61.

${ }^{98}$ Ibid para 76.

${ }^{99}$ Contrast with the Article 11 claim in Refah where the Court found that the party's policies were anti-democratic and thus contrary to the entire ethos of the Convention (n 68). The Court in Salvation Army concluded that despite its para-military structure and appearance "[i]t could not seriously be maintained that the applicant branch advocated a violent change of constitutional foundations or thereby undermined the integrity or security of the State" (n 94) para 92.

${ }^{100}$ G Davies (n 10) 528.
} 
which is apparently given protection by Article 9, it looks like plain disparity of treatment. Those whose rights happen to be closely connected with the core principles of the human rights canon are awarded the benefit of a high level of judicial scrutiny when it is alleged that those rights are interfered with. But for those with rights at the periphery, rights less dear to the hearts of the high priests of the doctrine, the Court's scrutiny is virtually "absent". The comments of Malcolm Evans are perhaps apposite:

Increasingly the doctrine of human rights is claimed to be the single universal framework within which all views must fit. One might say it has all the hallmarks of a proselytising religion and advocates the adoption of a particular world view which does not necessarily reflect the views of individuals in some religious cultures. ${ }^{101}$

One could surely forgive the Muslim woman or girl, claiming the right to wear a garment that she sincerely believes is required by her religion, for thinking that it looks like a case of "one rule for them and another one for me". There is nothing on the face of the European Convention to suggest that freedom of religion should be accorded less weight than freedom of political speech or sexual privacy but this is the clear implication of the case law: those rights that are valued by the liberal, pluralist, autonomy valuing culture (that very Enlightenment culture from which human rights originally grew) are valued more highly than those rights based on pre-Enlightenment religious values whose adherents stress divinely ordained obligation. ${ }^{102}$

It may be, as suggested above, that restriction on religious dress is justifiable and proportionate in specific contexts. There may be strong arguments favouring restrictions on school pupils (children are more in need of protection from domestic and doctrinal pressures) ${ }^{103}$ and school teachers (who are in a unique position of influence over impressionable minors and are also state representatives). ${ }^{104}$ The problem with the judgment in Şahin is that the Grand Chamber of the European Court did not even conduct a meaningful proportionality analysis - the linchpin of balancing rights of individuals against the wider interest.

\section{CONCLUDING REMARKS}

It might be contended that it is the international nature of the Şahin judgment that explains it; that it is of only limited use in national contexts. The especial political sensitivity of Turkey's situation, on the borders of Syria, Iraq and Iran and facing the real threat from within of extreme Islamist political parties gaining power and seeking "to impose on society as a whole their religious symbols and conception of a society founded on religious precepts" may help explain the judgment. ${ }^{105}$ The Grand Chamber, citing the Chamber judgment, made specific mention of the "Turkish

\footnotetext{
${ }^{101}$ M Evans (n 54) 183. See also A Bradney (n 57); J Martinez-Torron "The European Court of Human Rights and Religion" in R O'Dair and A Lewis Law and Religion (OUP Oxford 2001) 185, 203; F Raday (n 10); S Langlaude (n 33).

${ }^{102}$ F Raday (n 10) 663; A Bradney (n 57) 24.

${ }^{103}$ Begum (n 5) especially the speech of Baroness Hale, para 97; F Raday (n 10) 663.

${ }^{104}$ Dahlab (n 5); For arguments on the German "headscarf-teacher case" (n 5) see C Langenfeld and S Mohsen (n 83); O Gerstenberg "Freedom of Conscience in Public Schools" (2005) 3 International Journal of Constitutional Law 94.

${ }^{105}$ Refah Partisi (n 66) para 107-8.
} 
context". ${ }^{106}$ There are hints that if the Court were to scrutinise these issues in any greater depth it would risk opening a Pandora's box.

Something of the force of this special pleading is, perhaps, diluted when it is remembered that the zenith of Northern Irish political terrorism in the 1970s, 80s and 90s saw a slew of cases brought against the United Kingdom. Despite the fact that this terrorism posed extreme threats to public safety and, indeed, the territorial integrity of the United Kingdom itself very little quarter was given by the Court on the grounds of the political sensitivity of the situation. ${ }^{107}$

The Grand Chamber of the European Court of Human Rights is the most authoritative human rights court in Europe. It is probable, especially given the current climate of fear of extremist Islam and the anti-multiculturalist backlash, that the Şahin judgment will be used by national authorities to justify policies of restriction. After all, if the restriction of an adult university student, not herself posing any threat, is held to be "necessary in [Turkey's] democratic society", albeit against a backdrop of threats from extremist political organisations, then states wishing to curtail what children wear in schools, or even what adults wear in public space, will be able to use the judgment as authority. Since many western European states may now claim to be threatened by extremist Islam themselves, ${ }^{108}$ the judgment of the Grand Chamber may ease the way for national authorities wishing to impose restrictions on religious dress.

Perhaps something along these lines can be divined from the recent judgment of the Judicial Committee of the House of Lords in the case of Shabina Begum. ${ }^{109}$ It was held that a school's refusal to allow a Muslim school girl to wear a jilbab (long Islamic cloak), after it had formulated its uniform policy (having consulted with local faith groups) so as to include the option of a shalwar kameeze and headscarf, was not a breach of her Article 9 rights. This was because she had the opportunity to attend other schools at which the jilbab was permitted. In their speeches several of their Lordships commented on the balance struck having regard to the actual facts of the case and the specific concerns of the school authorities including evidence of fears expressed by other pupils. Lord Bingham observed that " $[\mathrm{t}] \mathrm{he}$ school had taken immense pains to devise a uniform policy which respected Muslim beliefs but did so on an inclusive, unthreatening and uncompetitive way. The rules . . . were as far from being mindless as uniform rules ever could be". ${ }^{110}$ The judgment allows a proper balance to be struck, a proportionality analysis to be undertaken, having regard to the actual facts of the case. ${ }^{111}$ Their Lordships did just what the European Court did not do in Şahin.

Interestingly Lord Hoffmann considered the relevance of the margin of appreciation, granted in Sahin, to the deliberations of the domestic court. In his view the doctrine "as such" had no application. Instead there was an "area of judgment within which the judiciary [would] defer, on democratic grounds, to the considered opinion of the elected body or person whose act or decision [was] said to be

\footnotetext{
${ }_{106}^{106}$ Şahin (n 11) para 115.

107 See eg Brogan v UK (1988) 11 EHRR 117; McCann v UK (1995) 21 EHRR 97. It is worth remembering that during this period the United Kingdom Cabinet was blown up in the Grand Hotel, Brighton on 12 October 1984 and 10 Downing Street was subjected to a mortar attack on 7 February 1991. I am grateful to Peter Cumper for this point.

${ }^{108}$ E Manningham-Buller (n 8).

${ }^{109}$ Begum (n 5).

${ }^{110}$ Ibid para 33.

${ }^{111}$ Indeed their Lordships rejected the "procedural" approach of the Court of Appeal (n 61), which had found that the school had approached the issue from the "wrong direction" rather than deciding on the substance of the matter. See Lord Bingham paras 27-31, Lord Hoffmann para 68.
} 
incompatible with the Convention". ${ }^{112}$ The margin of appreciation allowed by the Strasbourg court translated domestically into judicial deference to local decision makers:

It is for the courts of the United Kingdom to decide how the area of judgment allowed by that margin should be distributed between the legislature, executive and judicial branches of government. (emphasis added) ${ }^{113}$

In the United Kingdom [in contrast to Turkey] there is no national rule on these matters. Parliament has considered it right to delegate to individual schools the power to decide whether to impose requirements about uniforms which may interfere with the manifestation of religious beliefs. From the point of view of the Strasbourg court, the margin of appreciation would allow Parliament to make this choice. (emphasis added) $)^{114}$

In applying the principles of Şahin $v$ Turkey the justification must be sought at local level and it is there that an area of judgment, comparable to the margin of appreciation, must be allowed to the school. (emphasis added) ${ }^{115}$

These words may hold the seeds of potential problems; the leeway allowed to schools by Parliament, which is permissible in human rights terms because of the margin of appreciation afforded on this issue by the Strasbourg Court, is troubling. It would seem to require the municipal court to abstain from any intensive scrutiny of a uniform policy which interfered with the right to manifest religious belief through clothing. Take, for example, a school which refused to permit the Muslim headscarf or the Jewish kippa, in a situation (unlike in Begum) where there was no reasonably accessible alternative school. The latitude required to be shown to the school as a result of the translation of the margin of appreciation in to the domestic sphere would apparently permit such restriction and require only the bare minimum of judicial scrutiny. Those with beliefs far less radical than Shabina Begum may find their ability to manifest religion in their schools and colleges severely curtailed, with scant protection from the courts.

It is, perhaps, inevitable that religion will be afforded less protection in the human rights canon than rights with more instrumental value or whose exercise takes place wholly within the private domain. As Malcolm Evans says:

human rights and religion do not mix very easily and attempts to make them do so are fraught with difficulties and dangers. It may be possible for them to be brought together in a glorious symbiosis but the experience to date has not been encouraging . .. 116

Nevertheless it is submitted that the very least that can be expected from the courts in their adjudication on such matters is that they use the tools of their trade and conduct

\footnotetext{
${ }^{112}$ Begum (n 5) para 63 citing the dicta of Lord Hope in $R v$ Director of Public Prosecutions, Ex parte Kebilene [2000] 2 AC 326 at 381.

${ }^{113}$ Begum (n 5) para 62.

114 Ibid para 63.

${ }^{115}$ Ibid para 64

${ }^{116} \mathrm{M}$ Evans (n 54) at 177.
} 
a meaningful enquiry into the alleged breach of rights. ${ }^{117}$ The philosophical basis for religious freedom may be difficult to pin down, but the freedom is nevertheless protected by the European Convention on Human Rights. It is the function of European Court to protect all the rights set out in the Convention and subject state restrictions of these rights to serious and detailed analysis. It should not adopt the intellectually lazy option of running for the cover provided by the margin of appreciation as a way of avoiding difficult issues. If, as a result of the factors mentioned in part I of this article, European states do wish to curtail religious manifestation through dress the answer lies in an amendment to Article 9, not in the Court sidestepping its duty and as a result bringing the Convention system for the protection of human rights into disrepute. The current approach may justifiably provoke the following question from an individual wishing to manifest her faith by the clothing she wears: "Why do you tell us we have these freedoms when you are so obviously not prepared to protect them?"118

Tom Lewis*

\footnotetext{
${ }^{117}$ The recent approach of the majority of the Supreme Court of Canada demonstrates how courts may drill down into the facts of individual cases rather than accept generalised fears as justifying prohibition: Multani v Commission scolaire Marguerite-Bourgeoys and AG of Quebec [2006] SCC 6.

${ }_{118}$ Paraphrasing the comment of a Muslim woman interviewed in Unveiled BBC Radio 4, 12 October 2006.

*Nottingham Law School, Nottingham Trent University. I am grateful to Peter Cumper, Catherine Lewis, Adrian Walters and an anonymous referee for their helpful comments on earlier drafts. Errors and omissions remain my own.
} 